\title{
The Effect of Styles of Leadership, Conflict Management and Communication Organization to Team Performance
}

\author{
(Case Study of Construction Management Consultant at Gelora Bung Karno \\ Renovation Project Jakarta) \\ Lenny Ch Nawangsari ${ }^{{ }^{*}}$, Ahmad Hidayat Sutawidjaya ${ }^{2}$ \\ ${ }^{I}$ Magister Management, Mercu Buana University, Jakarta, Indonesia \\ ${ }^{2}$ Doctoral Management, Mercu Buana University, Jakarta, Indonesia
}

*Corresponding Author: Lenny Ch Nawangsari, Magister Management, Mercu Buana University, Jakarta. Indonesia

\begin{abstract}
This study aims to analyze the influence of Leadership Style, Conflict Management and Organizational Communication to Performance of Construction Management Consultant Team by using quantitative approach and survey method. The sample of research used 57 people. Data were collected using questionnaires with Likert scale 1-5. The data analysis technique used is GSCA. The result of this research proves that: 1) Leadership style has a direct and positive influence on Team Performance, 2) Conflict Management has a direct and positive impact on Team Performance, 3) Organizational Communication has a direct and positive impact on Team Performance, 4) Leadership style has direct and positive influence to organizational Communication, 5) Conflict Management has a direct and positive influence on organizational communication, 6) Leadership style directly influence to Team Performance through mediation Organizational communication, and 7) Conflict Management directly influence to Team Performance through Organizational Communication.
\end{abstract}

Keywords: Leadership Style, Conflict Management, Organizational Communication, Team Performance, Construction Management Consultant

\section{INTRODUCTION}

The field of construction services as one of the most important sectors in determining the steps of economic activity and becoming a driver in other sectors need to get attention and serious handling. It is intended to get the desired project quality, on time and with optimal cost. The relevant parties in the construction services industry whether owners, consultants, contractors and government agencies and private in demand to work well and professionally. They are required to improve their performance. The performance of consultants is not only determined by the head of the company, but by all aspects that contribute to the company including the work team in the project. A team that is formed and successful in completing a job is not necessarily suitable to be applied in another job. A team is made up of diverse people who are united in such a way as a unity. A solid and strong team is the key to a company's success, not a handful of great individuals working alone on the team. Leadership style is one of the factors that quite affect the performance in the team. leadership lies behind every successful program run by the team, and leadership must be able to initiate and direct the team. Besides, in managing a team often appear various conflicts.

Some researchers consider that the conflict is detrimental to the organization because it must be minimized. Actually conflict is also useful in an organization in making a change and spur innovation. As we know that conflict can not be avoided in social entities, such as organizations, teams and individuals. Conflict arises because of the friction because of the difference of interest in achieving the goal. Workplace conflicts can occur in interpersonal relationships between subordinates, superiors and co-workers in a group or between groups. One important component in building a good teamwork is the effective communication within the team. Communication can strengthen or weaken and even destroy a team. Good communication can build the strength of a team, whereas bad communication can destroy it. 
In relation to the above mentioned phenomena, the researcher wants to know whether organizational communication mediates the leadership style and conflict management to improve Team performance in construction management consultant.

\section{LITERATURE REVIEW}

\subsection{Leadership Style}

According to the path-goal theories of different styles of leadership can occur and are used as real by the same leader in different situations. The path-goal theory of the House version includes four main types or styles of leadership as follows:

1. Leadership directive, this type is the same as the autocratic leadership model of Lippitt and White. The subordinate knows exactly what is expected of him and the special direction given by the leader. In this mode there is no participation from subordinates.

2. Supportive leadership. The leadership of this model has a willingness to explain itself, be friendly, approachable and have pure humanitarian concern for its subordinates.

3. Participatory leadership. This leadership style, leaders seek to ask and use the suggestions of his subordinates. But decision-making still lies with him.

4. Achievement-oriented leadership. This style of leadership sets a set of goals that challenge their subordinates to excel. Similarly, leaders give confidence to them that they are able to carry out the job tasks to achieve goals well.

\subsection{Conflict Management}

Conflict management is a conflicting party process or a third party develops a conflict strategy and applies to control conflict to produce the desired resolution (Wirawan, 2010). Conflict management is also a way of leadership in stimulating conflict, reducing conflict and resolving conflicts aimed at improving individual performance and organizational productivity (Ade Florent, 2010).

The dimensions of conflict management according to Thomas \& Kilman (in Wirawan, 2010) are:

1. Cooperativeness: Collaboration and Compromise

2. Assertiveness: Competition and avoid

\subsection{Organizational Communication}

Organizational communication is an organizing behavior that occurs and how those involved in the process transact and give meaning to what happens (Faules, 2001). The dimensions and indicators of organizational communication consist of:

1. Internal Communication: Vertical Communication \& Horizontal Communication

2. External Communication: Organization to Audience \& Audience to the Organization

\subsection{Team Performance}

According to Mondy (2008) performance appraisal is a formal system to assess and evaluate the performance of the duties of employees, both individuals and teams. While Wilson (2012) states performance is the result of work achieved by someone based on job requirements. A job has certain requirements to be accomplished in achieving a goal which is also called the standard of work. This performance can be seen from several factors, namely: 1) Number of Work, 2) Quality of work, 3) Timeliness, 4) Attendance, 5) Cooperative ability.

Several previous studies related to leadership style and team performance are the Abdul Research (2015) which proves that leadership influences team performance. While research related to the influence of conflict management on team performance is done by Nesterkin (2016) stating that conflict management influence on Team Performance. Rico's research (2005) which proves that good communication will affect Team performance.

Based on previous theoretical and research studies then the hypothesis proposed is:

Hypothesis 1 : Leadership style has a direct and positive influence on Team Performance

Hypothesis 2 : Conflict Management has a direct and positive impact on Team Performance

Hypothesis 3 : Organizational communication has a direct and positive impact on Team

Performance 
The Effect of Styles of Leadership, Conflict Management and Communication Organization to Team Performance

Hypothesis 4 : Leadership style has a direct and positive influence on organizational communication

Hypothesis 5 : Conflict Management has a direct and positive influence on organizational communication

Hypothesis 6 : Leadership style has a direct effect on Team Performance through Communication Organization mediation

Hypothesis 7 :Conflict Management directly affects Team Performance through organizational communication.

\section{RESEARCH METHODS}

This research uses quantitative approach with survey method conducted on employees Construction Management Consultant Renovation Project Gelora Bung Karno Main Stadium with a total sample of 57 people. All variables in the study were measured using a Likert scale of 1-5.

\section{RESUlts AND DisCUSSION}

This study uses Generalized Structured Component Analysis (GSCA). The analysis steps are as follows:

\subsection{Testing Measurement Model}

There are 3 (three) criteria to assess the measurement model:

\subsubsection{Convergent Validity}

Convergent validity test describes the correlation measure between the reflective indicator score and the latent variable score. For this loading $\geq 0.40$ is considered valid.

Testing Results Convergent validity can be seen in Table 1.

Table1. Convergent Validity Test Results

\begin{tabular}{|l|l|l|l|l|}
\hline No & \multicolumn{1}{|c|}{ Variables } & \multicolumn{1}{c|}{ Indicators } & \multicolumn{1}{c|}{ Note } \\
\hline 1 & Leadership style & $(\mathrm{X} 1.1)$ & 0.749 & Valid \\
\hline & & $(\mathrm{X} 1.2)$ & 0.766 & Valid \\
\hline & & $(\mathrm{X} 1.3)$ & 0.843 & Valid \\
\hline & & $(\mathrm{X} 1.4)$ & 0.660 & Valid \\
\hline 2 & Conflict Management & $(\mathrm{X} 2.1)$ & 0.838 & Valid \\
\hline & & $(\mathrm{X} 2.2)$ & 0.833 & Valid \\
\hline 3 & Organizational communication & $(\mathrm{Y} 1.1)$ & 0.932 & Valid \\
\hline & & $(\mathrm{Y} 1.2)$ & 0.868 & Valid \\
\hline 4 & Team Performance & $(\mathrm{Y} 2.1)$ & 0.838 & Valid \\
\hline & & $(\mathrm{Y} 2.2)$ & 0.772 & Valid \\
\hline & & $(\mathrm{Y} 2.3)$ & 0.685 & Valid \\
\hline & & $(\mathrm{Y} 2.4)$ & 0.596 & Valid \\
\hline
\end{tabular}

Table describes the estimated value at loading in each indicator variable $\geq 0.40$ it can be concluded that the variable is valid

\subsubsection{Discriminant Validity}

In testing the discriminant validity of an instrument is said to be valid discriminant if $\sqrt{ }$ AVE is greater than the correlation coefficient of variables concerned with the others. Discriminant validity test results can be seen in table 2 .

Table2. Test results of Discriminant Validity

\begin{tabular}{|l|l|l|l|l|l|l|}
\hline & AVE & $\begin{array}{l}\text { Leadership } \\
\text { style (X1) }\end{array}$ & $\begin{array}{l}\text { Conflict } \\
\text { Management } \\
(\mathbf{X 2})\end{array}$ & $\begin{array}{l}\text { Organizational } \\
\text { communication } \\
(\text { Y1) }\end{array}$ & $\begin{array}{l}\text { Team Perfor- } \\
\text { mance (Y2) }\end{array}$ & Note \\
\hline Leadership style (X1) & 0,547 & 1 & $0.064(0.130)^{*}$ & $0.147(0.152)^{*}$ & $0.271(0.122)^{*}$ & Valid \\
\hline $\begin{array}{l}\text { Conflict } \\
\text { Management (X2) }\end{array}$ & 0,698 & $\begin{array}{l}0.064 \\
(0.130)^{*}\end{array}$ & 1 & $0.334(0.135)^{*}$ & $0.320(0.117)^{*}$ & Valid \\
\hline $\begin{array}{l}\text { Organizational } \\
\text { communication (Y1) }\end{array}$ & 0,811 & $\begin{array}{l}0.147 \\
(0.152)^{*}\end{array}$ & $0.334(0.135)^{*}$ & 1 & $0.619(0.084)^{*}$ & Valid \\
\hline $\begin{array}{l}\text { Team Performance } \\
\text { (Y2) }\end{array}$ & 0,530 & $\begin{array}{l}0.271 \\
(0.122)^{*}\end{array}$ & $0.320(0.117)^{*}$ & $0.619(0.084)^{*}$ & 1 & Valid \\
\hline
\end{tabular}


The Effect of Styles of Leadership, Conflict Management and Communication Organization to Team Performance

Table 2 explains that in all research variables $\sqrt{ } \mathrm{AVE}$ is greater than the correlation coefficient between variables concerned with other variables. Thus the research instrument is valid discriminant.

\subsubsection{Internal Consistensy}

In testing Internal consistency Reliability of an instrument is said to be reliable when the alpha value is above 0.60 . The results of the research reliabillity test can be seen in Table 3 .

Table3. Reliability Test Results of Research Instruments

\begin{tabular}{|l|l|l|}
\hline Variables & Alpha & Note \\
\hline Leadership style (X1) & 0.740 & Reliabel \\
\hline Conflict Management (X2) & 0.668 & Reliabel \\
\hline Organizational communication (Y1) & 0.758 & Reliabel \\
\hline Team Performance (Y2) & 0.699 & Reliabel \\
\hline
\end{tabular}

Table 3 shows that all variables yield an alpha value above 0.60 thus it can be concluded that the research instrument has good internal consistency reliability.

\subsection{Evaluation of Goodness-of-Fit Structural Model and Overall Model}

Result of Analysis with GSCA Method obtained by fit model contained in Table 4

Table4. Evaluation of Goodness-of-fit Structural Model and Overall Model on GSCA

\begin{tabular}{|l|l|}
\hline \multicolumn{2}{|c|}{ MODEL FIT } \\
\hline FIT & 0.500 \\
\hline AFIT & 0.477 \\
\hline GFI & 0.986 \\
\hline SRMR & 0.079 \\
\hline NPAR & 29 \\
\hline
\end{tabular}

The results of the above analysis can be said enough to meet the requirements of Goodness-Of-Fit.

\section{HYPOTHESIS TESTING}

\subsection{Hypothesis Testing and Coefficient of Direct Effect Line}

Hypothesis testing and path coefficient of direct influence between variables of Leadership Style, Conflict Management, Communication and Organizational Performance. Direct impact test can be seen from the value of path coefficient and critical point (CR *) which is significant at $\alpha=0,05$. The test results of direct influence between the variables in detail can be seen in table 5 .

Table5. Coefficient of Direct Effect Line and Hypothesis Testing

\begin{tabular}{|c|c|c|c|c|}
\hline No & Direct Correlation & Path Coef & C.R. (Uji t) & Conclusion \\
\hline 1 & $\begin{array}{l}\text { Leadership style }(\mathrm{X} 1) \quad \rightarrow \quad \text { Organizational } \\
\text { communication (Y1) }\end{array}$ & 0.126 & $2.38^{*}$ & Significant \\
\hline 2 & Leadership style (X1) $\rightarrow$ Team Performance (Y2) & 0.182 & $2.29^{*}$ & Significant \\
\hline 3 & $\begin{array}{l}\text { Conflict Management } \quad(\mathrm{X} 2) \rightarrow \quad \text { Organizational } \\
\text { communication (Y1) }\end{array}$ & 0.325 & $2.30^{*}$ & Significant \\
\hline 4 & Conflict Management $(\mathrm{X} 2) \rightarrow$ Team Performance $(\mathrm{Y} 2)$ & 0.125 & $2.35^{*}$ & Significant \\
\hline 5 & $\begin{array}{l}\text { Organizational communication (Y1) } \rightarrow \text { Team } \\
\text { Performance (Y2) }\end{array}$ & 0.550 & $5.45^{*}$ & Significant \\
\hline
\end{tabular}

Description * = significant at $\alpha=0.05$

Based on the above analysis the results obtained Hypothesis Testing Research as follows:

\section{H1: Leadership style has a direct and positive impact Team Performance}

The results of the analysis indicate that there is empirical evidence that the H1 hypothesis that "Leadership Style has a direct and positive effect on Team Performance" is accepted. The acquisition results of this analysis indicate that a good leadership style will affect team performance improvement.

\section{H2: Conflict Management has a direct and positive impact on Team Performance}

The results of the analysis indicate that there is empirical evidence that the hypothesis $\mathrm{H} 2$ which states that "Conflict Management has a direct and positive effect on Team Performance" is accepted. The 
The Effect of Styles of Leadership, Conflict Management and Communication Organization to Team Performance

results of this analysis show that good conflict management in a team will improve Team performance.

\section{H3: Organizational communication has a direct and positive impact on Team Performance}

The results of the analysis indicate that there is empirical evidence that the hypothesis $\mathrm{H} 3$ which states that "Organizational communication have a direct and positive effect on Team Performance" is accepted. The acquisition results of this analysis indicate that an increase in organizational communication will affect Team performance.

\section{H4: Leadership style has a direct and positive influence on Organizational Communication}

The results of the analysis indicate that there is empirical evidence that the hypothesis $\mathrm{H} 4$ which states that "Leadership style has a direct and positive effect on Organizational Communication" is accepted. The acquisition results of this analysis indicate that a good leadership style will improve organizational communication.

\section{H5: Conflict management has a direct and positive impact on Organizational Communication}

The results of the analysis indicate that there is empirical evidence that the hypothesis H5 which states that "Management of conflicts directly and positive influence on Organizational Communication" is accepted. The acquisition of the results of this analysis shows that good conflict management will improve organizational communication.

\section{H6: Leadership style has a direct influence on Team Performance through Communication Organization mediation}

The results of the analysis indicate that there is empirical evidence that the hypothesis H6 which states that "Leadership style directly affect the Team Performance through mediation Communications Organization" accepted. The acquisition of the results of this analysis indicates that Organizational communication mediates the relationship between leadership style and team performance.

H7: Conflict Management directly affects Team Performance through the mediation of Organizational communication

The results of the analysis indicate that there is empirical evidence that $\mathrm{H} 7$ hypothesis states that "Conflict Management directly affects Team Performance through Communication mediation" is accepted. The acquisition results of this analysis show that organizational communication mediates the relationship between conflict management and team performance.

\subsection{Examination of Mediation Influence Line Coefficient}

In general, the results of the Mediation Path Coefficient test are shown in Table 6.

Table6. Coefficient of Mediation Influence Line

\begin{tabular}{|c|c|c|c|c|c|c|c|}
\hline \multirow[t]{2}{*}{ No } & \multirow{2}{*}{$\begin{array}{l}\text { Correlation } \\
\text { Variables }\end{array}$} & \multirow{2}{*}{$\begin{array}{l}\text { Mediation } \\
\text { variable }\end{array}$} & \multicolumn{4}{|c|}{ Path coefficient } & \multirow[t]{2}{*}{ Conclusion } \\
\hline & & & $\mathbf{A}$ & B & $\mathbf{C}$ & d & \\
\hline 1 & $\begin{array}{l}\text { Leadership } \\
(\mathrm{X} 1) \stackrel{\text { style }}{\rightarrow} \rightarrow \text { Team } \\
\text { Performance (Y2) }\end{array}$ & $\begin{array}{l}\text { Organizational } \\
\text { communication } \\
\text { (Y1) }\end{array}$ & $0.182^{*}$ & $0.069^{*}$ & $0.126^{*}$ & $0.550^{*}$ & $\begin{array}{l}\text { Partial } \\
\text { Mediation }\end{array}$ \\
\hline 2 & $\begin{array}{l}\text { Conflict } \\
\text { Management }(\mathrm{X} 2) \rightarrow \\
\text { Team Performance } \\
(Y 2)\end{array}$ & $\begin{array}{l}\text { Organizational } \\
\text { communication } \\
\text { (Y1) }\end{array}$ & $0.125^{*}$ & $0.179^{*}$ & $0.325^{*}$ & $0.550^{*}$ & $\begin{array}{l}\text { Partial } \\
\text { Mediation }\end{array}$ \\
\hline
\end{tabular}

Description $*=$ significant at $\alpha=0.05$

Based on the above analysis it is proven that the variable of Organizational Communication as the mediation variable in the relationship of the path of leadership style to the Team Performance and the relationship of Conflict Management to Team Performance with Partial Mediation.

\subsection{Line Analysis Model}

Based on the analysis conducted, it can be arranged path path model of influence as in Figure 1. 


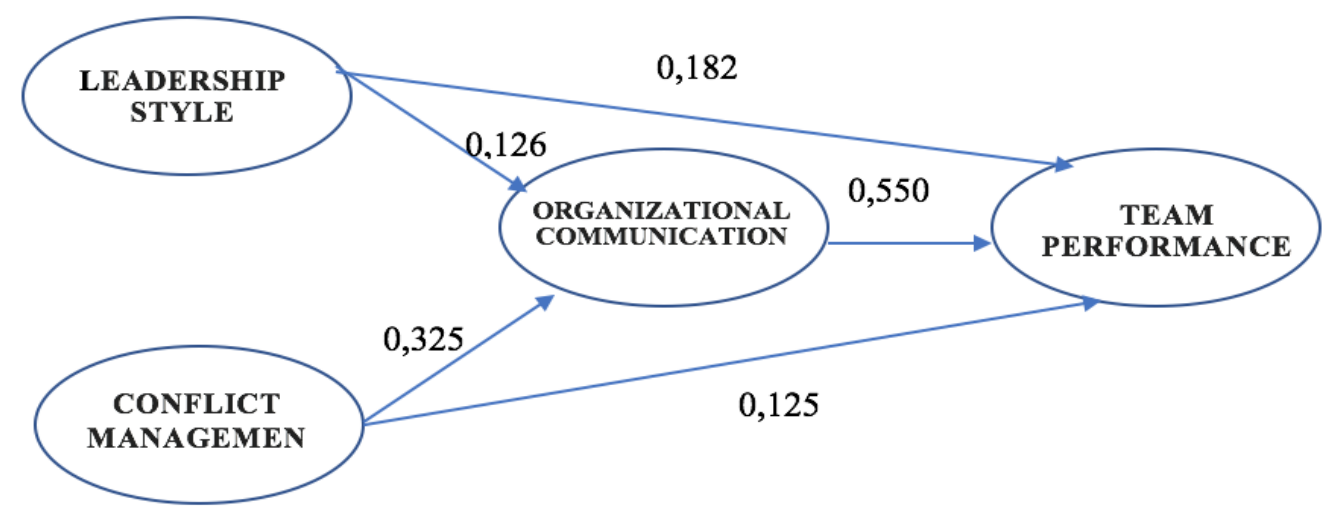

Figure1. Line Analysis Model

Figure 1 shows the existence of 5 direct influences namely 1) Leadership style has a significant effect on Team Performance; 2) Conflict Management has significant influence on Team Performance; 3) Organizational communication has significant influence on Team Performance; 4) Leadership style has significant influence on organizational communication; and 5) Conflict management has a significant effect on organizational communication. Besides, there are 2 indirect influences, namely: 1) Leadership Style on Team Performance through Organizational Communication and 2) Conflict Management on Organizational Performance through Organizational Communication.

\subsection{Testing Loading Factor}

The loading factor assessment is used to find out the strongest indicator of the variable meter. The highest loading factor value shows the strongest variable gauge indicator that is interpreted as an indicator with the dominant contribution to reflect the variables. The result of the mean value recapitulation and the loading factor of each indicator variable is shown in Table 7.

Table7. Estimate Loading Recapitulation

\begin{tabular}{|l|l|l|l|}
\hline \multirow{2}{*}{ Variable } & \multicolumn{2}{|l|}{ Instruments } & $\begin{array}{l}\text { Estimate } \\
\text { Loading }\end{array}$ \\
\hline Leadership style (X1) & Directive & X1.1 & 0.749 \\
\hline & Supportive & $\mathrm{X} 1.2$ & 0.766 \\
\hline & Participatory & $\mathrm{X} 1.3$ & $0.843^{*}$ \\
\hline & Achievement & $\mathrm{X} 1.4$ & 0.660 \\
\hline Conflict Management (X2 & Cooperativeness & $\mathrm{X} 2.1$ & $0.838^{*}$ \\
\hline & Asertiveness & $\mathrm{X} 2.2$ & 0.833 \\
\hline Organizational communication (Y1) & Internal & Y1.1 & $0.932^{*}$ \\
\hline & Eksternal & Y1.2 & 0.868 \\
\hline Team Performance (Y2) & Quantity & Y2.1 & $0.838^{*}$ \\
\hline & Quality & Y2.2 & 0.772 \\
\hline & Presence & Y2.3 & 0.685 \\
\hline & Kerjasama & Y2.4 & 0.596 \\
\hline
\end{tabular}

Note $*$ = Nilai loading factor terbesar/ tertinggi

\section{DISCUSSION}

\subsection{The Influence of Leadership Style on Team Performance}

Leadership style influences Team Performance. The findings of this study are in line with research conducted by Abdul's Research (2015) which proves that leadership influences team performance. The research result proves that the most influential characteristic of leadership style is participative leadership style compared to the other 3 leadership styles which are directive leadership style, supportive and achievement. Participative leadership style is a leadership style where leaders still involve their subordinates in making decisions. In Team work in Leadership Construction Management Consultant is a very important thing where most of Team members consist of experts from various disciplines in the field of construction. In completing the work required a leader who can accommodate various opinions to solve complex problems to improve Team performance. 


\subsection{The Influence of Conflict Management on Team Performance}

Conflict Management Affects Team Performance meaning that good conflict management in a team will affect Team performance improvement to company. The findings of this study are in line with the results of Nesterkin's (2016) study which states that conflict management affects Team Performance. The results show that conflict management is good enough. Characteristics The most influential conflict management is the characteristic of Cooperativeness.

\subsection{The Influence of Organization Communication on Team Performance}

Organizational Communication influence on Team Performance. This means that good communication within the team will improve team performance. This finding reinforces the results of previous research conducted by Rico (2005) which proves that good communication will affect Team performance. The results of the study found that the dominant characteristics affecting in communication are the characteristics of internal communication compared to external communication.

\subsection{The Effect of Leadership Style on Organizational Communication}

Leadership style influences organizational communication meaning that proper leadership style can improve communication effectiveness in team work. The research findings indicate that the leadership style in the organization under study is still not optimal and needs to be improved so that it will increase the effectiveness in team and organizational communication.

\subsection{The Influence of Conflict Management on Organizational Communication}

Conflict management affects organizational communication. This means that good conflict management will improve communication with the Team. This study proves that the existence of appropriate conflict management affects the existence of good communication in the organization. Associated with organizational communication need to improve communication that is external.

\subsection{The Influence of Leadership Style on Team Performance through Organizational Communication}

The results of this study prove the existence of Leadership Style on Team Performance through Organizational Communication. The right leadership style in a work team can affect organizational communication. Good communication within the organization will lead to improved Team performance. Team performance in this research is reflected in quality factor, quantity, attendance and cooperation. The factors that most influence quantity are followed by quality of work.

\subsection{The Influence of Conflict Management on Team Performance through Organizational Communication}

This study proves the influence of conflict management on team performance through organizational communication. Field findings indicate that good conflict management in teams will affect communications that impact on improving team performance. Improved conflict management by way of compromise, negotiation and collaboration is necessary so that it will improve Team performance.

\section{CONCLUSION}

1. Specifically the results of this study can be summarized as follows:

2. Leadership style has a direct and positive impact on Team Performance. This means that a Leadership Style that fits the Team's condition can improve the performance of the Construction Management Consultant Team.

3. Conflict Management has a direct and positive impact on Team Performance. The results show that good management of Conflict Management can improve the performance of Construction Management Consultant Team.

4. Organizational communication has a direct and positive impact on Team Performance. Optimal communication within the organization is able to influence the improvement of the Performance Management Consultant Team.

5. Leadership style has a direct and positive influence on Organizational Communication. This indicates that the Leadership Style possessed by the leader in the organization can influence improve the effectiveness of Organizational Communication. 
6. Conflict management has a direct and positive influence on organizational communication. This suggests that proper management of conflict management will improve the effectiveness of organizational communication.

7. The style of leadership directly affects Team Performance through mediation of organizational communication. The optimal leadership style in the team is needed to improve the quality of organizational communication so as to improve the performance of the Construction Management Consultant Team.

8. Conflict management directly affects Team performance through mediation of organizational communication. This suggests that proper management of conflicts within a work team will be able to influence the effectiveness of communication within the organization and lead to improved performance of the Construction Management Consultant Team.

This research provides theoretical implications for the development of Human Resource Management Science, particularly in the areas of leadership, conflict management, organizational communication and team performance.

Limitations in this study are as follows: 1) This study was conducted at a construction management company in the city of Jakarta; 2) The instrument used in this study is a closed questionnaire so as not yet fully able to control the honesty and accuracy of the respondent's answer whether in accordance with the actual reality. Based on the weaknesses in this study can be suggested for further research: 1) Further research can examine more about other variables that affect organizational communication and team performance 2) Further research can develop indicators on conflict management and organizational communication; and 3) Further research can conduct similar research by extending the research area to know the consistency of the findings.

\section{REFERENCE}

[1] Amstrong, Michael. (2010). Human Resource Management.Kogan Page Limited. Great Britain and the United States.

[2] Bangun, Wilson. (2012). Manajemen Sumber Daya Manusia. Penerbit Erlangga. Bandung.

[3] Dmitriy Nesterkin Tobin Porterfield,(2016),"Conflict management and performance of information technology development teams", Team Performance Management, Vol. 22 Iss 5/6 pp. 242 - 256

[4] Linda S. Wing, (2005), Leadership in high-performance teams: a model for superior team performance; Team Performance Management Vol. 11 no 2, pp. 4-11

[5] Mondy, R. Wayne. (2008). Manajemen Sumber Daya Manusi. Jilid 1 Edisi 10. Erlangga. Jakarta.

[6] Robbins, SP dan Judge. (2008). Perilaku Organisasi, Salemba Empat. Jakarta

[7] Ramón Rico Susan G. Cohen, (2005),"Effects of task interdependence and type of communication on performance in virtual teams", Journal of Managerial Psychology, Vol. 20 Iss 3/4 pp. 261 - 274

[8] Sitompul, Ade Florent S. (2010). "Pengaruh Manajemen Konflik Terhadap Kinerja Karywan pada Karyawan PT. PLN (PERSERO) Cabang Medan". Skrips tidak diterbitkan. Fakultas Ekonomi Univesitas Sumatra Utara

[9] Srinivasa Rao Waheed Kareem Abdul, (2015),"Impact of transformational leadership on team performance: an empirical study in UAE", Measuring Business Excellence, Vol. 19 Iss 4 pp-

[10] Thoha, Mifta. (2014). Perilaku Organsiasi: Konsep Dasar dan Aplikasinya. Rajawali Pers. Jakarta

[11] Wirawan. (2010). Konflik dan Manajemen Konflik Teori, Aplikasi, dan Penelitian. Jakarta: Salemba Humanika.

Citation: Lenny Ch Nawangsari, Ahmad Hidayat Sutawidjaya. " The Effect of Styles of Leadership, Conflict Management and Communication Organization to Team Performance." International Journal of Humanities Social Sciences and Education (IJHSSE), vol 5, no. 7, 2018, pp. 1-8. doi: http://dx.doi.org/10.20431/23490381.0507001 .

Copyright: ( 2018 Authors. This is an open-access article distributed under the terms of the Creative Commons Attribution License, which permits unrestricted use, distribution, and reproduction in any medium, provided the original author and source are credited. 